\title{
The tyranny of the use of homologous series of chemical odorants in olfactory research: does the olfactory system recognize molecules or odors?
}

\author{
James M Bower \\ From 1st International Workshop on Odor Spaces \\ Hannover, Germany. 4-7 September 2013
}

In some sense, the idea that the olfactory system is a chemical component analyzer can be traced to the hypothesis attributed to Titus Lucretius Carus in 50B.C. that human olfactory perception is directly linked to the general features of the shape of the molecules that " penetrare putes primordial forma in naris hominum" (i.e. "work their way into the nostrils of men"). Consistent with this ancient hypothesis, for much of the last 200 years, the dominate experimental approach used to probe the functional organization of the olfactory system has involved the presentation of carefully selected homologous series of chemical compounds organized, for example, according to carbon chain length. In this presentation, data will be presented suggesting that, in fact, this may be entirely the wrong metric to use in understanding olfaction and olfactory perception. Based on an analysis of the organization of industry standard odor descriptors, we have proposed instead that the olfactory system might be organized to detect specific metabolic pathways, in effect already incorporating into its structure and circuitry a deep understanding of the metabolic world. As a test of this hypothesis, human psychophysical data will be presented suggesting that molecules derived from the same metabolic pathways are more likely to interfere perceptually than are molecules that are simply structurally similar. Preliminary data will also be presented suggesting that primary olfactory receptors themselves might be organized as metabolic pathway detectors, rather than as traditional detectors of molecular structure. Finally, evidence will be briefly presented that this "understanding" of the metabolic world might be built into the neural networks of the olfactory system itself. This proposal is based on the results of realistic model-based

\footnotetext{
University of Texas, Health Science Center at San Antonio, San Antonio,
} Texas TX, USA

(c) 2014 Bower; licensee BioMed Central Ltd. This is an Open Access article distributed under the terms of the Creative Commons Attribution License (http://creativecommons.org/licenses/by/2.0), which permits unrestricted use, distribution, and reproduction in any medium, provided the original work is properly cited. The Creative Commons Public Domain Dedication waiver (http:// creativecommons.org/publicdomain/zero/1.0/) applies to the data made available in this article, unless otherwise stated. and take full advantage of:

- Convenient online submission

- Thorough peer review

- No space constraints or color figure charges

- Immediate publication on acceptance

- Inclusion in PubMed, CAS, Scopus and Google Scholar

- Research which is freely available for redistribution Submit your manuscript at
www.biomedcentral.com/submit C BioMed Central 